\title{
Gene transfer to Clostridium cellulolyticum ATCC 35319
}

\author{
Katrin C. B. Jennert, ${ }^{1}+$ Chantal Tardif, ${ }^{2,3}$ Danielle I. Young ${ }^{1}$ \\ and Michael Young ${ }^{1}$
}

Author for correspondence: Michael Young. Tel: +44 1970 622348. Fax: +44 1970622307 e-mail: miy@aber.ac.uk

\footnotetext{
1 Institute of Biological Sciences, Cledwyn Building, University of Wales, Aberystwyth, Penglais SY23 3DD, UK

2 Laboratoire de Bioénergétique et Ingénierie des Protéines, CNRS, 31 Chemin Joseph Aiguier, 13402 Marseille Cedex 20, France

3 Université de Provence, Marseille, France
}

\begin{abstract}
Although much is known about the bacterial cellulosome and its various protein components, their contributions to bacterial growth on cellulose and the process of cellulolysis in vivo cannot currently be assessed. To remedy this, the authors have developed gene transfer techniques for Clostridium cellulolyticum ATCC 35319 . Firstly, transfer of Tn1545 has been obtained using an Enterococcus faecalis donor. Secondly, IncP-mediated conjugative mobilization of plasmids from Escherichia coli donors has also been achieved. The yield of transconjugants in both cases was low and was probably limited by the suboptimal growth conditions that must of necessity be employed for the co-culture of oligotrophic C. cellulolyticum with copiotrophic donors. A restriction endonuclease was detected in crude extracts of $C$. cellulolyticum. This enzyme, named Ccel, is an isoschizomer of Mspl (Hpall). Electrotransformation was employed to establish plasmids containing the replication functions of pAM/11 (En. faecalis), pIM13 (Bacillus subtilis), pCB102 (Clostridium butyricum), pIP404 (Clostridium perfringens) and pWV01 (Lactococcus lactis subsp. cremoris) in C. cellulolyticum. Transformants were only obtained if the DNA was appropriately methylated on the external $C$ of the sequence 5'-CCGG$3^{\prime}$ using either BsuFI methylase in vivo or Mspl methylase in vitro. Plasmids based on the pAM $\beta 1$ and pIM13 replicons were more stably maintained than one based on the PCB102 replicon. Selection of transformants on solid medium led to low apparent transformation efficiencies (approx. $10^{2}$ transformants per $\mu g$ DNA) which might, in part, reflect the low plating efficiency of the organism. Selection of transformants in liquid medium led to a higher apparent yield of transformants (between $10^{5}$ and $10^{7}$ transformants per $\mu \mathrm{g}$ DNA). The methods developed here will pave the way for functional analysis of the various cellulosome components in vivo.
\end{abstract}

Keywords: conjugation, electro-transformation, methylation, cellulosome

\section{INTRODUCTION}

The bacterial cellulosome is a multi-component cellsurface organelle found in several species of Clostridium, as well as in certain other organisms (Felix \& Ljungdahl, 1993; Shoham et al., 1999). This sophisticated complex of cellulolytic enzymes has been characterized most extensively in the thermophilic species Clostridium thermocellum (Bayer et al., 1998; Shoham et al., 1999). A considerable amount is also known about the cellulosomes of two mesophilic

† Present address: Department of Biological Sciences, The Open University, Walton Hall, Milton Keynes, UK. species, C. cellulovorans (Doi et al., 1998) and C. cellulolyticum (Bélaich et al., 1997; Gal et al., 1997; Pagès et al., 1997, 1999; Reverbel-Leroy et al., 1997). This last species has also been quite extensively characterized physiologically (Giallo et al., 1985; Gelhaye et al., 1993a, b; Guedon et al., 1999a, b; Payot et al., 1998). To date, molecular analysis of the bacterial cellulosome has been based exclusively on studies of recombinant proteins (Bayer et al., 1998; Bélaich et al., 1997). Functional analysis 'in clostridio' still awaits the development of suitable laboratory protocols for effecting gene transfer.

Gene transfer to many species of Clostridium is now possible using a variety of methods, including protoplast 
transformation, electro-transformation and conjugation (reviewed by Young \& Cole, 1993; Young et al., 1999). Moreover, allelic replacement, which is essential for the analysis of gene function in vivo, has been achieved in three species, C. beijerinckii (Wilkinson \& Young, 1994), C. acetobutylicum (Green et al., 1996) and C. perfringens (Awad et al., 1995).

An ever-growing range of clostridia has been electrotransformed (Young et al., 1999 and references therein). The activity of host restriction enzymes remains a significant barrier to electro-transformation with double-stranded DNA. If the nature of the restriction system is known, transforming DNA may be protected by methylation in vivo or in vitro (Mermelstein \& Papoutsakis, 1993; Davis et al., 2000). As an alternative to electro-transformation, the extremely broad-hostrange conjugation machinery of IncP plasmids may be employed to mobilize plasmids from Escherichia coli to a wide range of Gram-positive bacteria (Trieu-Cuot et al., 1987). Vectors containing the cis-acting oriT site (origin of transfer) of the IncP plasmid RK2 are mobilized if all other conjugation functions are provided in trans on an IncP plasmid or as part of the donor chromosome. This method was initially optimized for C. beijerinckii (Williams et al., 1990a, b) and it has since been employed for transferring DNA to other clostridia (Young et al., 1999 and references therein).

Conjugative transposons are useful tools for insertional mutagenesis and mutational cloning (Clewell \& Flannagan, 1993; Young, 1993a, b; Scott \& Churchward, 1995). The most widely used representatives are the broad host-range streptococcal transposons, Tn916 (Franke \& Clewell, 1981) and Tn1545 (Courvalin \& Carlier, 1987). One or other of these elements has been transferred to a wide range of clostridia (Young et al., 1999 and references therein).

Although the number of clostridia that are amenable to genetic analysis is constantly increasing, there have been no reports so far of gene transfer to cellulolytic species. [Note, however, that $\operatorname{Tn} 1545$ has been transferred to Eubacterium cellulosolvens (Anderson et al., 1998), which is a very close relative of the clostridia.] We describe herein the development of conjugation and electro-transformation procedures for Clostridium cellulolyticum ATCC 35319, which we have employed to establish a range of plasmids as well as a conjugative transposon in this organism. They represent a first step towards functional analysis of the cellulosome in clostridio.

\section{METHODS}

Bacterial strains and plasmids. These are summarized in Tables 1 and 2 .

Culture media and bacterial growth. Strains of E. coli were maintained on Luria-Bertani medium (Sambrook et al., 1989). C. cellulolyticum ATCC 35319 was routinely grown on GS medium, modified from that described by Garcia-Martinez et al. (1980), which contains: $\mathrm{KH}_{2} \mathrm{PO}_{4}, 3.7 \mathrm{mM} ; \mathrm{K}_{2} \mathrm{HPO}_{4}, 3.5 \mathrm{mM}$; urea, $33 \mathrm{mM} ; \mathrm{MgCl}_{2}, 2.5 \mathrm{mM} ; \mathrm{CaCl}_{2}, 0.3 \mathrm{mM} ; \mathrm{FeSO}_{4}$, $0.004 \mathrm{mM}$; sodium $\beta$-glycerophosphate, $28 \mathrm{mM}$; trisodium citrate, $10 \mathrm{mM}$; MOPS, $48 \mathrm{mM}$; D-cellobiose, $15 \mathrm{mM}$; cysteine. $\mathrm{HCl}, 6.3 \mathrm{mM}$; yeast extract, $0.5 \%$ (w/v); pH 7.2. VM medium was derived from GS medium by replacing yeast extract with: D-biotin, $0.08 \mu \mathrm{M}$; pyridoxamine, $0.02 \mu \mathrm{M}$; cyanocobalamin, $0.001 \mu \mathrm{M} ; p$-aminobenzoic acid, $0.15 \mu \mathrm{M}$; thiamin, $0.9 \mu \mathrm{M}$; L-alanine, $0.22 \mu \mathrm{M}$. Bacterial growth was monitored by following the $\mathrm{OD}_{600}$ with time. The generation time in this medium is approx. $6 \mathrm{~h}$ at $34^{\circ} \mathrm{C}$. GS and VM were solidified with $1.5 \%(\mathrm{w} / \mathrm{v})$ agar, as appropriate.

Filter mating procedure. The optimized procedure was adapted from that of Williams et al. (1990a) as follows. Donor strains of E. coli and Enterococcus faecalis were grown overnight, at $37^{\circ} \mathrm{C}$ in aerobic conditions, to stationary phase in brain heart infusion broth (BHIB, Oxoid) supplemented with $50 \mu \mathrm{g}$ ampicillin $\mathrm{ml}^{-1}$ and $10 \mu \mathrm{g}$ erythromycin $\mathrm{ml}^{-1}$, selective for their mobilizable plasmid or conjugative transposon, respectively. The following morning, donor strains were diluted back ten-fold and regrown to $\mathrm{OD}_{600}>1 \cdot 0$ (about $5 \times 10^{8}$ c.f.u. $\mathrm{ml}^{-1}$ ). Alternatively, they were diluted with an equal volume of pre-warmed BHIB. Donor cells were washed twice in pre-warmed BHIB just before mating, to remove traces of the selective antibiotic. All manipulations involving the recipient, C. cellulolyticum ATCC 35319, were carried out at $34^{\circ} \mathrm{C}$ in an anaerobic workstation (Don Whitley Scientific). The recipient was grown for $17-24 \mathrm{~h}$ in GS medium to late exponential phase at $\mathrm{OD}_{600} 0 \cdot 5-1 \cdot 0$ (about $5 \times 10^{6}$ c.f.u. $\mathrm{ml}^{-1}$ ). The low number of c.f.u. recovered is due, in part, to a tendency to grow in filaments, but this organism also shows a low plating efficiency. Donor and recipient cells were mixed at a $10: 1$ ratio by pipetting $0 \cdot 2 \mathrm{ml}$ donor culture into $2 \mathrm{ml}$ recipient culture. The bacteria were harvested by filtration through a nitrocellulose filter (Whatman WCN, pore size $0.45 \mu \mathrm{m}, 25 \mathrm{~mm}$ diameter). Filters were incubated overnight at $34^{\circ} \mathrm{C}$, bacteria uppermost, on plates spread with $2 \mathrm{mg}$ catalase (Sigma). For matings with E. coli donors, GS medium was used; for matings with En. faecalis donors, VM medium was used. Bacteria were harvested from the filters the following morning by vortex mixing in $0.5 \mathrm{ml}$ holding buffer $(1 \mathrm{mM}$ $\mathrm{MgSO}_{4}, 25 \mathrm{mM}$ potassium phosphate, $\mathrm{pH} \mathrm{7 \cdot 0)}$ and serial dilutions were prepared in this buffer. Viable counts of donor and recipient bacteria were obtained by plating on BHIB and either GS (for E. coli matings) or VM (for En. faecalis matings), respectively. Recipient bacteria were counterselected by aerobic incubation whereas donor bacteria were counter-selected by incorporation of $10 \mu \mathrm{g}$ trimethoprim $\mathrm{ml}^{-1}$ (E. coli) or the absence of a fermentable carbon source (En. faecalis). Transconjugants were selected anaerobically on the above media supplemented with $10 \mu \mathrm{g}$ erythromycin $\mathrm{ml}^{-1}$. Transconjugants appeared 4-5 d after plating. Transfer frequencies were expressed as the number of transconjugants per recipient colony formed after the mating period.

E. coli donor strains were constructed by introducing the plasmids to be mobilized into a strain of HB101 in which the IncP $\beta$ plasmid, R702 (Thomas \& Smith, 1987), was already present.

Characterization of the restriction system. Crude extracts of C. cellulolyticum were prepared from a $20 \mathrm{ml}$ lateexponential-phase culture, using the method described by Azeddoug \& Reysset (1991). The soluble cellular extract was adjusted to $50 \%(\mathrm{v} / \mathrm{v})$ glycerol and stored at $-20^{\circ} \mathrm{C}$. For restriction assays, 350-400 ng DNA substrate was mixed with $2.5 \mu \mathrm{l}$ of crude extract (approx. $10 \mu \mathrm{g}$ protein) and incubated for $2 \mathrm{~h}$ at $37^{\circ} \mathrm{C}$ in $25 \mu \mathrm{l}$ of $10 \mathrm{mM}$ Tris/ $\mathrm{HCl}, \mathrm{pH} 7 \cdot 5$, buffer containing $50 \mathrm{mM} \mathrm{NaCl}, 10 \mathrm{mM} \mathrm{MgCl}_{2}, 1 \mathrm{mM}$ dithioerythritol, $0.01 \%$ BSA. The products were analysed by electrophoresis through agarose $(1 \cdot 2 \%, \mathrm{w} / \mathrm{v})$. For methylation 
Table 1. Bacterial strains

\begin{tabular}{|c|c|c|}
\hline Strain & Genotype or phenotype* & Source/reference \\
\hline \multicolumn{3}{|l|}{$\begin{array}{l}\text { Clostridium } \\
\text { cellulolyticum }\end{array}$} \\
\hline H10 (ATCC 35319) & Wild-type & $\begin{array}{l}\text { E. Petitdemange, } \\
\text { Nancy/Petitdemange } \\
\text { et al. (1984) }\end{array}$ \\
\hline \multicolumn{3}{|l|}{ Escherichia coli } \\
\hline $\mathrm{DH} 5 \alpha$ & 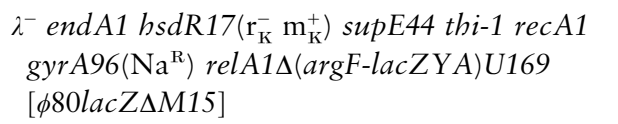 & Hanahan (1985) \\
\hline \multicolumn{3}{|l|}{ Escherichia coli } \\
\hline HB101 & $\begin{array}{l}\mathrm{F}^{-} \text {hsd } 220\left(\mathrm{r}_{\mathrm{B}}^{-} \mathrm{m}_{\mathrm{B}}^{-}\right) \text {endol recA13 supE44 ara-14 } \\
\text { proA2 galK2 rpsL20 }\left(\mathrm{Sm}^{\mathrm{R}}\right) \text { xyl-5 mtl-1 }\end{array}$ & $\begin{array}{l}\text { Laboratory } \\
\text { strain/Boyer \& } \\
\text { Roulland-Dussoix } \\
(1969)\end{array}$ \\
\hline \multicolumn{3}{|l|}{ Escherichia coli } \\
\hline TOP10 & $\begin{array}{c}\mathrm{F}^{-} \text {mcrA } \Delta(\text { mrr-hsdRMS-mcrBC })[\phi 80 \Delta l a c Z \Delta \\
\text { M15] } \Delta \text { lacX74 deoR recA1 araD139 } \Delta(\text { ara- } \\
\text { leu }) 7679 \text { galU galK rpsL }\left(\mathrm{Sm}^{\mathrm{R}}\right) \text { endA1 nupG }\end{array}$ & Appligene \\
\hline \multicolumn{3}{|l|}{$\begin{array}{l}\text { Enterococcus } \\
\text { faecalis }\end{array}$} \\
\hline BM4110: : Tn1545 & $\left(\operatorname{Em}^{\mathrm{R}} \mathrm{Tc}^{\mathrm{R}} \mathrm{Km}^{\mathrm{R}}\right.$ Fus $\left.^{\mathrm{R}} \operatorname{Rif}^{\mathrm{R}}\right)$ & $\begin{array}{l}\text { P. Courvalin, Institut } \\
\text { Pasteur/Courvalin \& } \\
\text { Carlier (1986) }\end{array}$ \\
\hline
\end{tabular}

*Antibiotic-resistance markers have been abbreviated as follows: Em, erythromycin; Fus, fusidic acid; Km, kanamycin; Na, nalidixic acid, Rif, Rifampicin; Sm, streptomycin; Tc, tetracycline.

Table 2. Plasmids

\begin{tabular}{|c|c|c|c|}
\hline Plasmid & Relevant characteristics & $\begin{array}{c}\mathrm{Gram}^{+} \\
\text {replicon }\end{array}$ & Source or reference \\
\hline R702 & 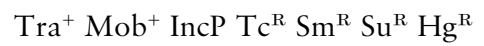 & - & Hedges \& Jacob (1974) \\
\hline pAT187 & $\mathrm{Tra}^{-} \mathrm{Mob}^{+} \mathrm{Km}^{\mathrm{R}}$ & $\mathrm{pAM} \beta 1$ & Trieu-Cuot et al. (1987) \\
\hline pM.BsuF1 & $\mathrm{Met}^{+} \mathrm{Cm}^{\mathrm{R}}$ & - & Davis et al. (2000) \\
\hline pMTL540 & $\mathrm{Ap}^{\mathrm{R}}, \mathrm{Em}^{\mathrm{R}}$ in $\mathrm{Gram}^{+}$hosts & pCB102 & N. P. Minton, CAMR \\
\hline pCTC1 & $\begin{array}{l}\mathrm{Tra}^{-} \mathrm{Mob}^{+} \mathrm{Ap}^{\mathrm{R}}, \mathrm{Em}^{\mathrm{R}} \text { in } \mathrm{Gram}^{+} \\
\text {hosts }\end{array}$ & $\mathrm{pAM} \beta 1$ & Williams et al. (1990b) \\
\hline pGK12 & $\mathrm{Tra}^{-} \mathrm{Mob}^{-} \mathrm{Cm}^{\mathrm{R}} \mathrm{Em}^{\mathrm{R}}$ & pWV01 & Kok et al., 1984 \\
\hline pJIR418 & $\operatorname{Tra}^{-} \mathrm{Mob}^{-} \mathrm{Cm}^{\mathrm{R}} \mathrm{Em}^{\mathrm{R}}$ & pIP404 & Sloan et al., 1992 \\
\hline pCTC501 & $\begin{array}{l}\operatorname{Tra}^{-} \mathrm{Mob}^{+} \mathrm{Ap}^{\mathrm{R}}, \mathrm{Em}^{\mathrm{R}} \text { in } \mathrm{Gram}^{+} \\
\text {hosts }\end{array}$ & pCB101 & Young et al. (1993) \\
\hline pCTC511 & $\begin{array}{l}\operatorname{Tra}^{-} \mathrm{Mob}^{+} \mathrm{Ap}^{\mathrm{R}}, \mathrm{Em}^{\mathrm{R}} \text { in } \mathrm{Gram}^{+} \\
\text {hosts }\end{array}$ & pCB101 & Williams et al. (1990b) \\
\hline $\mathrm{pECII}$ & $\mathrm{Ap}^{\mathrm{R}}, \mathrm{Em}^{\mathrm{R}}$ in $\mathrm{Gram}^{+}$hosts & pIM13 & Ph. Soucaille, INSA, Toulouse \\
\hline pECN2* & $\mathrm{Ap}^{\mathrm{R}}, \mathrm{Em}^{\mathrm{R}}$ in $\mathrm{Gram}^{+}$hosts, $5^{\prime}$ cipC & pIM13 & This paper \\
\hline
\end{tabular}

* Plasmid pECN2 is a derivative of pECII, containing a $1.6 \mathrm{kbp}$ fragment from entirely within the coding sequences of the $5^{\prime}$ end of cipC.

protection assays, HpaII methylase (M.HpaII) and MspI methylase (M.MspI) (New England Biolabs) were used according to the supplier's instructions. Methylated DNA was purified using QIAEX II (QIAGEN) before incubation with restriction endonucleases.
Electro-transformation procedures. C. cellulolyticum was grown for $17-24 \mathrm{~h}$ in $50 \mathrm{ml}$ cultures in GS medium to late exponential phase, i.e. $\mathrm{OD}_{600} \quad 0 \cdot 5-1 \cdot 0$ (about $5 \times 10^{6}$ c.f.u. $\mathrm{ml}^{-1}$ ). Bacteria were harvested by centrifugation in sealed tubes for $10 \mathrm{~min}$ at $6000 \mathrm{~g}$ and $4{ }^{\circ} \mathrm{C}$ in a Hettich EBA 
$12 \mathrm{R}$ centrifuge. Cells were washed twice with $10 \mathrm{ml}$ ice-cold electroporation buffer $\left(270 \mathrm{mM}\right.$ sucrose; $1 \mathrm{mM} \mathrm{MgCl}_{2} ; 5 \mathrm{mM}$ sodium phosphate buffer, $\mathrm{pH} 7 \cdot 4$ ) in the anaerobic chamber and resuspended in a final volume of $1 \mathrm{ml}$ of this buffer. Plasmid DNA (1-2 $\mu \mathrm{g})$ was added to pre-chilled electroporation cuvettes (Equibio, $0 \cdot 2-\mathrm{cm}$ inter-electrode distance) followed by $200 \mu \mathrm{l}$ cell suspension, and the cuvettes were incubated on ice for $10 \mathrm{~min}$.

In some experiments, bacteria were pulsed once at $1.5 \mathrm{kV}$, $25 \mu \mathrm{F}$ and $100 \Omega$ using a Bio-Rad Gene Pulser electroporation apparatus. The resulting pulse duration was 1.9-2.0 ms. Fresh GS medium (1 ml) was added to the cuvette immediately after electroporation and the cell suspension was transferred to a further $1 \mathrm{ml}$ GS for overnight incubation. The following morning, bacteria were harvested by centrifugation, resuspended in $200 \mu \mathrm{l} \mathrm{GS}$ and spread on two GS agar plates supplemented with $10 \mu \mathrm{g}$ erythromycin $\mathrm{ml}^{-1}$. Transformation efficiencies were expressed as the number of transformants per $\mu \mathrm{g}$ DNA. Since an $18 \mathrm{~h}$ period was allowed for phenotypic expression, during which two to three bacterial generations may have occurred, the transformation frequencies are probably overestimated by between four- and eightfold.

In some experiments, a JOUAN PS15 electropulsator (JOUAN, France) was used. This apparatus delivers square wave pulses, which provide a constant electric field of preprogrammed duration and voltage. The mixture containing $10^{9}$ cells and $10^{10}$ plasmid molecules (e.g. $80 \mathrm{ng}$ pCTC1) was subjected to a 5 -ms pulse at $6 \cdot 5,7$, or $7 \cdot 5 \mathrm{kV} \mathrm{cm}^{-1}$. The electroporated cells were incubated overnight in $10 \mathrm{ml}$ fresh GS medium before plating on solid medium and transformation efficiencies were evaluated as described above. Alternatively, after an overnight phenotypic expression period without antibiotic, the electroporated cells were subcultured in $100 \mathrm{ml}$ GS liquid medium supplemented with $10 \mu \mathrm{g}$ erythromycin $\mathrm{ml}^{-1}$. Growth of the transformed bacteria was monitored by following the $\mathrm{OD}_{600}$. Apparent transformation efficiencies were derived by extrapolating the growth curves to zero time (assuming exponential growth throughout). This gave a theoretical initial $\mathrm{OD}_{600}$ for the transformed fraction of the bacterial population. This value was converted into the theoretical number of transformants at $t_{0}\left(1 \mathrm{OD}_{600}\right.$ unit corresponds to a total count of $2 \cdot 3 \times 10^{8}$ cells ml ${ }^{-1}$ culture), from which the apparent number of transformants per $\mu \mathrm{g}$ DNA was derived. (Note that apparent transformation efficiencies will be underestimated if there is a lag before growth commences.)

Before electroporation, plasmid DNA was purified from E. coli $\mathrm{DH} 5 \alpha$ and then subjected to methylation in vitro using MspI methylase. In some experiments DNA was methylated in vivo using the Bacillus subtilis site-specific BsuFI methylase (Walter et al., 1990; Davis et al., 2000). Both of these enzymes methylate the sequence CCGG on the external cytosine. The gene encoding this enzyme was cloned in plasmid pACYC184 by T. Davis (CAMR, Porton Down), who kindly provided the resulting plasmid, pM.BsuFI, in the TOP10 strain of E. coli. This strain was transformed with the target plasmids. Total plasmid DNA was then extracted and used directly for electroporation experiments.

Molecular methods. The methods employed for DNA extraction and manipulation were those described by Sambrook et al. (1989). Large-scale plasmid extraction from E. coli was achieved using the QIAGEN Midi Prep Kit according to the manufacturer's instructions. For small-scale plasmid extraction from C. cellulolyticum, $6 \mathrm{ml}$ of an overnight culture was subjected to the extraction procedure described previously by
Williams et al. (1990a) for Clostridium beijerinckii NCIMB 8052. Total DNA was extracted using a method adapted from that of Noirot et al. (1987).

Methylases (New England Biolabs), restriction endonucleases (Promega, New England Biolabs) and T4 DNA ligase (Promega) were used according to the manufacturers' instructions. DNA fragments were purified using the QIAEX agarose extraction kit (QIAGEN). Transformation of E. coli strains DH5 $\alpha$, HB101 and TOP10 was carried out as described by Hanahan (1985).

Standard procedures were employed for Southern hybridizations (Southern, 1975). DNA fragments were transferred to a positively charged nylon membrane (Boehringer) and hybridized with digoxigenin-labelled probes (Boehringer). Plasmid pAT187 (Trieu-Cuot et al., 1987), which contains an aphA-3 gene very similar to that of Tn1545 (Caillaud et al., 1987), was employed to detect $\operatorname{Tn} 1545$.

\section{RESULTS}

\section{Transfer of pCTC1 to C. cellulolyticum by conjugation}

In some preliminary experiments (data not shown) the plasmid pCTC1, containing the replication machinery of the En. faecalis plasmid pAM $\beta 1$ (LeBlanc \& Lee, 1984), was transferred at a low frequency to C. cellulolyticum. The mating procedure was then optimized with respect to the following parameters: growth phase of the recipient, ratio of donor to recipient c.f.u. in the mating mixture, mating period and mating medium. This resulted in enhanced pCTC1 transfer frequencies, with values as high as $1.2 \times 10^{-5}$ transconjugants per recipient being obtained in some experiments. The most crucial parameters appeared to be the ratio $(10: 1)$ of donor to recipient c.f.u. in the mating mixture and the physiological state (mid-exponential) of the recipient. However, the optimized procedure was not always reproducible in our hands; even when all the above conditions were met, experiments sometimes failed or gave unacceptably low transfer frequencies of the order of $10^{-7}-10^{-8}$ per recipient. Plasmid DNA was isolated from four C. cellulolyticum transconjugants obtained in independent experiments. The presence of authentic pCTC1 was verified by looking for the characteristic pattern of restriction fragments obtained after EcoRI digestion (data not shown). Conjugative transfer and establishment of the plasmid pCTC501 (Young et al., 1993) could not be demonstrated using the optimized protocol.

\section{Transfer of Tn1545 to C. cellulolyticum by conjugation}

In mating experiments with the En. faecalis BM4110 donor, which contains multiple copies of Tn1545 (Woolley et al., 1989), Em ${ }^{\mathrm{R}}$ transconjugants were obtained at frequencies of between $1.7 \times 10^{-6}$ and $3.8 \times 10^{-8}$ per recipient. DNA was extracted from two independent transconjugants, digested with HindIII, EcoRI and PstI and the presence of Tn1545 was verified by Southern hybridization. A Tn1545-specific probe hybridized with multiple HindIII fragments in DNA 
$\begin{array}{lllllllllllll}1 & 2 & 3 & 4 & 5 & 6 & 7 & 8 & 9 & 10 & 11 & 121314\end{array}$

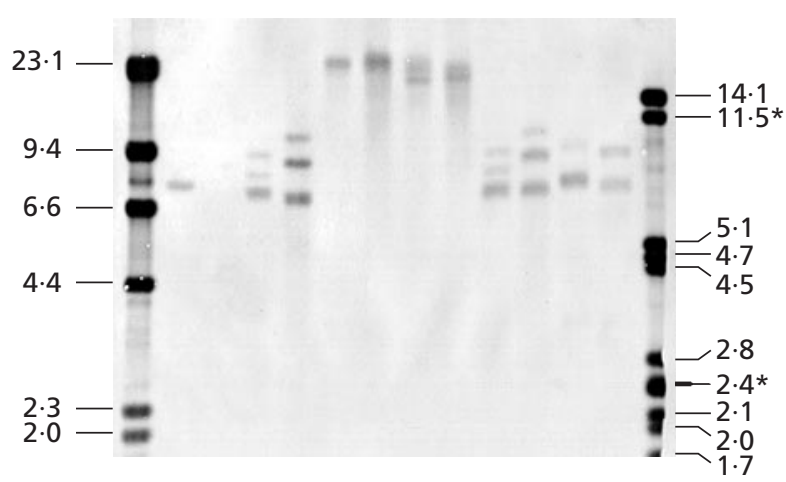

Fig. 1. Detection of $\operatorname{Tn} 1545$ in C. cellulolyticum transconjugants. DNA was isolated from two transconjugants (1 and 2) obtained in independent mating experiments between S. faecalis BM4110 and C. cellulolyticum. After digestion and blotting, DNA samples were hybridized with an aphA-3-specific probe, which detects junction fragments at the left end of Tn1545. Lanes 1 and 14 contain bacteriophage $\lambda$ DNA. Lanes 2 and 3 are controls containing DNA isolated from Clostridium beijerinckii strain $\mathrm{A} 10$ and $C$. cellulolyticum, respectively. The former harbours a single copy of Tn1545 (Evans et al., 1998), whereas the latter lacks the element. DNA from strain 1 is in lanes 4, 6, 8, 10 and 12; DNA from strain 2 is in lanes 5, 7, 9, 11 and 13. DNA samples were digested with Hindlll (lanes 1-5), EcoRI (lanes 6 and 7), Pstl (lanes 8 and 9), HindIII + EcoRI (lanes 10 and 11), or HindllI + Pstl (lanes 12 and 13). The bands marked with asterisks in lane 14 (2586 and 11497 bp fragments) associate during electrophoresis via their singlestranded cohesive ends to generate the band at $14.1 \mathrm{kbp}$.

isolated from both transconjugants, whereas no signal was detected with wild-type DNA (Fig. 1). Since HindIII does not cleave $\operatorname{Tn} 1545$ between the aphA-3 gene detected by hybridization and the left end of the element (Caillaud et al., 1987), hybridizing bands should correspond to junction fragments containing the transposon end and adjacent clostridial DNA. The presence of multiple bands normally reflects multiple sites of transposon insertion into the bacterial chromosome. However, the various fragments in Fig. 1 are not all of equivalent intensity, suggesting that some of them may be partial digestion products. The digestions with EcoRI and PstI alone are not informative in this regard, but the samples digested with PstI plus HindIII show simplified hybridization patterns, indicating that Tn1545 has probably inserted into at least three different sites in the two strains (strain 2 probably harbours two copies of $\operatorname{Tn} 1545)$.

\section{Characterization of a restriction system in C. cellulolyticum ATCC 35319}

Attempts to electro-transform C. cellulolyticum with various shuttle vectors were generally unsuccessful, suggesting that the organism has an active restriction system, responsible for degrading the incoming DNA. Many clostridia produce type II restriction enzymes (http://rebase.neb.com), which in some cases have (a)

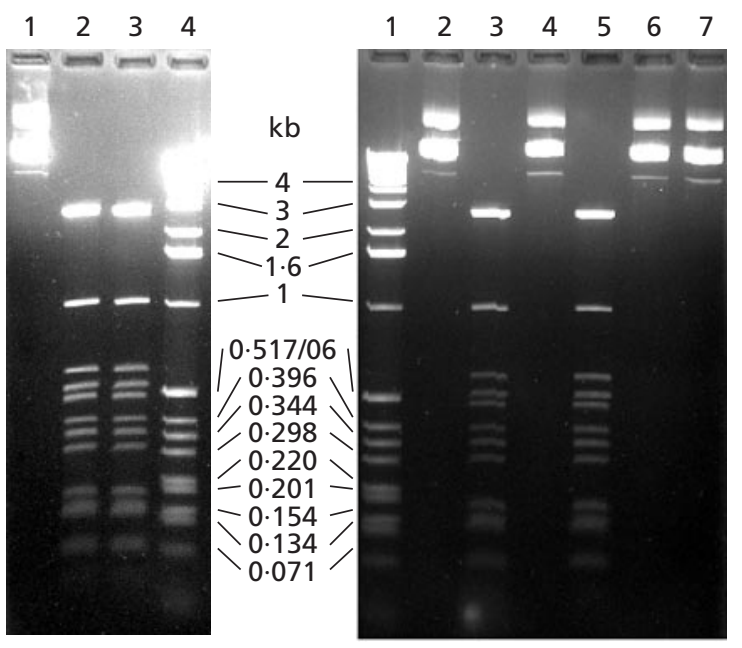

Fig. 2. The restriction system of C. cellulolyticum. (a) Determination of the restriction specificity using pJIR418. DNA Plasmid pJIR418 (lane 1) was incubated with C. cellulolyticum cell extract in lane 2 and with $\mathrm{Mspl}$ in lane 3. Lane 4 contains a $1 \mathrm{~kb}$ DNA extension ladder (Life Technologies). (b) Protection of DNA by methylation. $1 \mathrm{~kb}$ ladder (BRL) (lane 1); pJIR418 (lane 2 ), incubated with $C$. cellulolyticum cell extract (lane 3 ), methylated by M.Hpall and then incubated with Hpall (lane 4) or clostridial cell extract (lane 5), methylated by M.Mspl and then incubated with Mspl (lane 6) or C. cellulolyticum cell extract (lane 7).

proved to be responsible for low transformation efficiencies (Azeddoug et al., 1989; Mermelstein \& Papoutsakis, 1993). Incubation of plasmid pJIR418 (Fig. 2a, lane 1) with a crude extract of C. cellulolyticum resulted in a pattern of discrete DNA fragments (Fig. 2a, lane 2). Comparison of the number and sizes of the DNA fragments with the published restriction map of pJIR418 (http://www.infobiogen.fr) indicated that the crude extract contained an isoschizomer of MspI (HpaII) [5'CCGG-3'], which we have named CceI. The recognition specificity of $C c e$ I was verified by comparing the patterns of restriction fragments obtained after incubating pJIR418 DNA with the crude extract and with MspI (Fig. 2a, lanes 2 and 3).

\section{Protection of plasmids by methylation}

The recognition sequence 5'-CCGG-3' may be modified by two commercially available cytosine-specific methylases, M.HpaII and M.MspI (New England Biolabs). M.HpaII methylates the internal cytosine and M.MspI the external cytosine. These two enzymes were used to methylate the test plasmid pJIR418. Methylated DNA was then digested with a cell-free extract from $C$. cellulolyticum. The products were analysed by agarose gel electrophoresis (Fig. 2b) along with control samples of undigested (lane 2) and non-methylated, digested DNA (lane 3). Methylation of pJIR418 by M.HpaII (5'$\mathrm{C}^{\mathrm{m} 5}$ CGG-3') did not protect the DNA from CceI restriction (lane 5) although cleavage by the restriction 
Table 3. Frequencies of plasmid transfer to C. cellulolyticum

pECII, pMTL540E and pCTC511 were methylated in vivo, electro-transformed using the Bio-Rad Gene Pulser and transformation frequencies were derived by plating. pJIR418 and pGK12 were methylated in vitro, electro-transformed using the Bio-Rad Gene Pulser and transformation frequencies were not determined. pCTC1 was transferred using both methods.

\begin{tabular}{|c|c|c|c|c|c|}
\hline Plasmid & $\begin{array}{c}\text { Size } \\
(\mathbf{k b p})\end{array}$ & Replicon & Origin & $\begin{array}{c}\text { Antibiotic } \\
\text { resistance } \\
\text { marker" }\end{array}$ & $\begin{array}{c}\text { Transformation } \\
\text { efficiency } \neq \\
(\mu \mathrm{g} \text { DNA })^{-1}\end{array}$ \\
\hline pCTC1 & $7 \cdot 2$ & $\mathrm{pAM} \beta 1$ & Enterococcus faecalis & $\mathrm{Em}^{\mathrm{R}}$ & $10^{2}$ \\
\hline pECII & $4 \cdot 5$ & pIM13 & Bacillus subtilis & $\mathrm{Em}^{\mathrm{R}}$ & $2 \times 10^{2}$ \\
\hline pMTL540E & $5 \cdot 2$ & pCB102 & Clostridium butyricum & $\mathrm{Em}^{\mathrm{R}}$ & $0.5 \times 10^{2}$ \\
\hline pJIR418 & $7 \cdot 4$ & pIP404 & Clostridium perfringens & $\mathrm{Em}^{\mathrm{R}} \mathrm{Cm}^{\mathrm{R}} \dagger$ & $\mathrm{ND}$ \\
\hline pGK12 & $4 \cdot 5$ & pWV01 & $\begin{array}{l}\text { Lactococcus lactis subsp. } \\
\text { cremoris }\end{array}$ & $\mathrm{Em}^{\mathrm{R}} \mathrm{Cm}^{\mathrm{R}} \dagger$ & ND \\
\hline pCTC511 & $7 \cdot 8$ & pCB101 & Clostridium butyricum & $\mathrm{Em}^{\mathrm{R}}$ & no transformants \\
\hline
\end{tabular}

*All plasmids also encode resistance to ampicillin, selectable in E. coli.

$+\mathrm{Cm}^{\mathrm{R}}$ is present on these plasmids, but it was not used as a selective marker in this investigation.

$\ddagger$ Transformation efficiencies were derived from colony counts on solid medium.

ND, Not determined.

enzyme HpaII was prevented (lane 4). On the other hand, methylation of the external cytosine by M.MspI $\left(5^{\prime}-{ }^{m}{ }^{5} C C G G-3^{\prime}\right)$ protected the DNA against CceI restriction (lane 7).

\section{Transfer of plasmids to C. cellulolyticum by electro- transformation}

The ability to protect DNA from C. cellulolyticum endonuclease activity by methylation opened up the possibility of using electro-transformation as a method for transferring DNA to C. cellulolyticum. Electrotransformation of appropriately modified DNA (see Methods) was employed to introduce plasmids from several different Gram-positive bacteria into $C$. cellulolyticum (Table 3). As expected from the conjugation experiments (see above), pCTC1 containing the pAM $\beta 1$ replicon was successfully transferred. In addition, several other plasmids containing the replicons of the Bacillus subtilis plasmid, pIM13 (Monod et al., 1986; Azeddoug et al., 1992), the C. butyricum plasmid, pCB102 (Minton \& Morris, 1981; Collins et al., 1985), the C. perfringens plasmid, pIP404 (Garnier \& Cole, 1988 ) and the Lactococcus lactis subsp. cremoris plasmid, pWV01 (Leenhouts et al., 1991) also generated transformants. No transformants were obtained with plasmid pCTC511 containing the replicon of the C. butyricum plasmid, pCB101 (Collins et al., 1985; Brehm et al., 1992), nor were there any antibiotic-resistant colonies in controls lacking plasmid DNA.

The apparent transformation efficiencies obtained (approx. $10^{2}$ transformants per $\mu$ g DNA, see Table 3 ) were low when transformants were selected on solid medium after an overnight expression period. This value is nevertheless an overestimate, because cells potentially grew during the time allowed for phenotypic expression (two to three generations). To optimize the electro-transformation procedure and enhance transformation efficiencies, a JOUAN electropulsator was used. This delivers square wave pulses with constant electric field parameters over a programmed discharge duration (see Methods). The cell/plasmid (pCTC1) mixture was resuspended in a buffer containing either no sucrose, $270 \mathrm{mM}$ sucrose, or $500 \mathrm{mM}$ sucrose and was subjected to an electric field of $6 \cdot 5,7$, or $7 \cdot 5 \mathrm{kV} \mathrm{cm}^{-1}$ for $5 \mathrm{~ms}$. Transformants were only obtained with buffer containing $270 \mathrm{mM}$ or $500 \mathrm{mM}$ sucrose and at 7 or $7 \cdot 5 \mathrm{kV} \mathrm{cm}^{-1}$. Under successful electro-transformation conditions, transformation efficiencies evaluated on solid medium (as above) were approx. $10^{2}$ transformants per $\mu \mathrm{g}$ DNA. However, when plating was avoided using the liquid culture technique (see Methods), estimated values of between $10^{5}$ and $10^{7}$ transformants per $\mu \mathrm{g}$ DNA were obtained. Cells pulsed in the absence of plasmid DNA were incubated in selective liquid medium as a negative control. No visible growth was detected, showing that the selection of spontaneous antibioticresistant mutants did not interfere with these experiments. The large differences between apparent transformation efficiencies using solid versus liquid medium might be explained by the low plating efficiency of the bacteria, leading to a gross underestimation of transformation efficiency based on the appearance of colonies on solid medium.

Transformants obtained using pIM13- and pAM $\beta 1$ based plasmids were verified by extracting plasmid DNA from selected transformants and digesting it with diagnostic restriction endonucleases (Fig. 3). These data showed unequivocally that the pIM13 and pAM $\beta 1$ replicons function in C. cellulolyticum. Extraction yields of pJIR418 (pIP404-based plasmid) and pGK12 (pWV01-based plasmid) from C. cellulolyticum were 
(a)

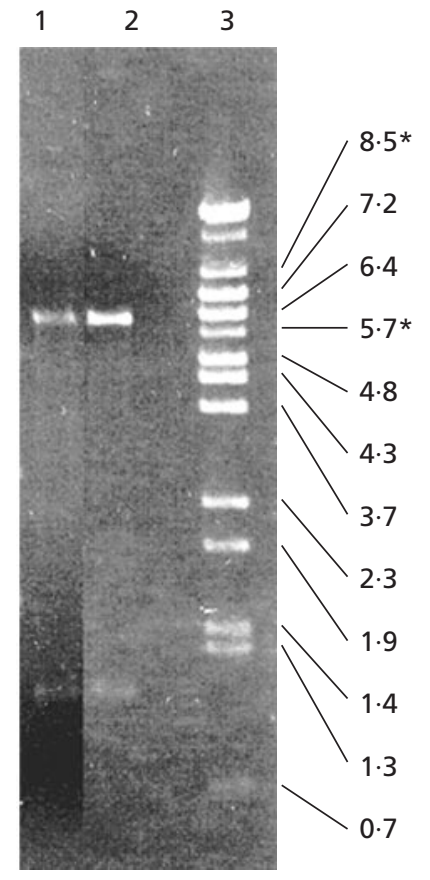

(b)

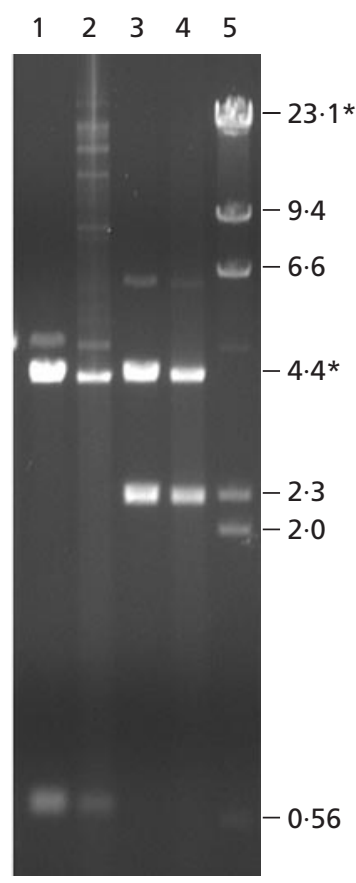

Fig. 3. Verification of plasmids isolated from C. cellulolyticum transformants. Plasmids were isolated from transformants obtained in independent experiments, as indicated in the Methods. (a) EcoRI-digested samples of pCTC1 (pAM $\beta 1$ replicon) from $E$. coli (lane 1) and C. cellulolyticum (lane 2); $\lambda$ BstEll marker (lane 3). (b) Sacl-digested samples of pECll (pIM13 replicon) from E. coli (lane 1) and C. cellulolyticum (lane 2); Sacl-digested samples of pECN2 from E. coli (lane 3 ) and C. cellulolyticum (lane 4); $\lambda$ Hindlll (lane 5). Some incomplete digestion products are visible in lanes 1-4.

much lower than those of pIM13- and pAM $\beta 1$-based plasmids, suggesting that these are maintained at lower copy numbers. This was not surprising, especially in the case of pGK12 which was maintained in Lactococcus lactis (formerly Streptococcus lactis) and Bacillus subtilis at three and five copies per cell, respectively (Kok et al., 1984).

\section{Plasmid stability in C. cellulolyticum}

To test the comparative stability of the various plasmids in C. cellulolyticum, strains carrying pCTC1, pECN2 and pMTL540E (pAM $\beta 1$, pIM13 and pCB102 replicons, respectively) were grown for 20 generations in the absence of selective antibiotic. Bacteria were then plated on GS agar and colonies were screened for plasmid loss by replica plating on selective and non-selective media. Frequencies of plasmid loss were approximated (Young \& Ehrlich, 1989) by dividing the proportion of antibiotic-sensitive colonies by the number of generations of bacterial growth. Similarly low values were obtained for pCTC1 and pECN2, containing the pAM $\beta 1$ and pIM13 replicons, namely $7 \cdot 8 \times 10^{-3}$ and $4.7 \times 10^{-3}$ per generation, respectively. The plasmid

pMTL540E, containing the $\mathrm{pCB} 102$ replicon, was rather less stable; the frequency of plasmid loss was $3 \cdot 6 \times 10^{-2}$ per generation.

\section{DISCUSSION}

The roles and functions of many of the components of the bacterial cellulosome have been extensively explored by analysis of recombinant gene products in vitro (see Bayer et al., 1998 for a review). Unfortunately, it has not so far been possible to undertake functional analysis of any of the genes or their products in vivo, since none of the cellulosome-producing organisms is amenable to genetic analysis. However, Anderson et al (1998) have very recently reported the low-frequency transfer of Tn1545 to the relatively poorly characterized organism Eubacterium cellulosolvens. The physiology (Giallo et al., 1985; Gelhaye et al., 1993a, b; Guedon et al., 1999a, b; Payot et al., 1998) and the cellulolytic machinery (Bélaich et al., 1997; Gal et al., 1997; Pagès et al., 1997, 1999; Reverbel-Leroy et al., 1997) of C. cellulolyticum ATCC 35319 are comparatively well characterized. Therefore we developed procedures for transferring Tn1545, as well as several different plasmids, to this organism using conjugation and/or electrotransformation.

Although the frequencies of conjugative plasmid transfer to C. cellulolyticum reported here were sometimes as high as $10^{-5}$ per recipient, reproducibility was poor. Previous experience (Williams et al., 1990a) indicated that high-efficiency, reproducible conjugation only occurs under conditions permitting good growth of both donor and recipient as they are co-cultured during the mating period. Since E. coli is a copiotroph and C. cellulolyticum is essentially an oligotroph, co-culture was always likely to prove problematic. Moreover, the low plating efficiency of C. cellulolyticum effectively meant that many potential transconjugants were lost in each experiment (although this is unlikely to affect the conjugation frequency). Similar problems pertained to the conjugative transfer of Tn1545 from En. faecalis to C. cellulolyticum, where even fewer transconjugants were often recovered. They may also account for the low frequencies of transfer of $\operatorname{Tn} 1545$ to Eu. cellulosolvens that were reported recently (Anderson et al., 1998). A single strand of DNA appears to be transferred during intergeneric conjugation (Young et al., 1993). Therefore, DNA that is transferred by conjugation does not normally have to run the gauntlet of the restriction endonucleases that may be present in the recipient (see below). If an alternative oligotrophic donor in which IncP plasmids can replicate is identified in the future, higher numbers of recombinants and elevated transfer frequencies may be obtained. This may ultimately permit the use of conjugative transfer of non-replicative plasmids to effect allelic exchange.

Insertional mutagenesis using Tn1545 is similarly limited by low transfer frequencies from the copiotrophic En. faecalis donor. The element apparently inserted into three different sites in the C. cellulolyticum chromosome 
(Fig. 1). The possibility that there is a preferred site for insertion in this organism (cf. the behaviour of the related element, Tn916, in C. difficile: Mullany et al., 1991) cannot be excluded until larger numbers of transconjugants have been analysed.

Electroporation proved to be a more reliable method for obtaining gene transfer, but only once the incoming DNA was protected from restriction. C. cellulolyticum ATCC 35319 protects its own DNA from restriction by methylation, and donor DNA that had been modified using an appropriate DNA methylase (M.BsuF1 or M.MspI $\left.\left[5^{\prime}-{ }^{\mathrm{m} 5} \mathrm{CCGG}-3^{\prime}\right]\right)$ gave reproducible electrotransformation. Vectors containing the replication functions of five different plasmids, originating from five different organisms, were able to function in C. cellulolyticum. Plasmids containing the replication regions of the $B$. subtilis ssDNA plasmid pIM13, the L. lactis ssDNA plasmid pWV01, the streptococcal thetareplicating plasmid pAM $\beta 1$ (Bruand et al., 1993), the C. perfringens theta-replicating plasmid pIP404 (Garnier $\&$ Cole, 1988) and pCB102 from C. butyricum, with its unknown mode of replication (Minton et al., 1993), were established with approximately equal efficiency. Although pCB101 is a ssDNA plasmid like pIM13 and, like pCB102, it originates from C. butyricum, we were unable to establish vectors (pCTC501 and pCTC511) containing this replicon in C. cellulolyticum, using either conjugation or electro-transformation.

The apparent transformation efficiencies for the various plasmids were rather low (approx. $10^{2}$ transformants per $\mu$ g DNA, see Table 3) when transformants were selected on solid medium. The reason for this seems to be the low plating efficiency of this strain. Substantially higher apparent efficiencies were obtained when a nonconventional method was employed to derive the number of transformants originally present. Essentially, the growth kinetics of transformed bacteria in liquid medium were measured and used to extrapolate the number of transformants initially present. These results open up the possibility of effecting allelic replacement and insertional inactivation of genes in C. cellulolyticum, using suicide plasmids. Stepwise gene replacement using replicative, but segregationally unstable vectors (Maguin et al., 1992; Biswas et al., 1993) could also provide a useful alternative. We therefore explored the segregational stability of three representative plasmids in C. cellulolyticum.

Plasmids that have been transferred to an organism in which they do not normally reside are frequently unstable (Gruss \& Ehrlich, 1988; Ehrlich et al., 1991; Minton et al., 1993). This instability may result from structural changes or from segregation of plasmid-less cells owing to inefficient plasmid replication and/or partitioning at cell division (Gruss \& Ehrlich, 1989). Instability of plasmids containing two of the replicons employed here has previously been reported in other clostridia (Oultram et al., 1988; Azeddoug et al., 1992). Frequencies of segregation of plasmid-less cells were $4.1 \times 10^{-2}$ per generation for a pAM $\beta 1$-based plasmid in
C. beijerinckii (Oultram et al., 1988) and $2 \cdot 3 \times 10^{-2}$ per generation for a pIM13-based plasmid in Clostridium saccharoperbutylacetonicum NI-4081 (Azeddoug et al., 1992). In C. cellulolyticum however, both the pAM $\beta 1$ (theta-replication) and the pIM13 (rolling circle, ssDNA plasmid) replicons were moderately stable in the absence of selection and segregated plasmid-less cells at frequencies of about $5 \times 10^{-3}$ per generation. In view of the behaviour of pIM13-based plasmids in other organisms (Azeddoug et al., 1992), the comparative stability of plasmids containing this replicon was unexpected. To explore the phenotypic consequences of disruption of $c i p C$, which encodes the scaffoldin component of the C. cellulolyticum cellulosome, several derivatives of the pIM13-based plasmid, pECII, (e.g. pECN2) were constructed with the intention of obtaining cipC disruption mutants of C. cellulolyticum. The comparative stability of these plasmids in this organism prevented us from pursuing this line of enquiry. In view of their reduced stability, it might be provident to employ pCB102-based plasmids for this purpose in the future.

The results we have obtained demonstrate that C. cellulolyticum ATCC 35319 is amenable to genetic analysis. Significant difficulties still to be circumvented are the low frequency of conjugative gene transfer, which is probably related to the oligotrophic nature of this organism, and the low plating efficiency. This makes it difficult to recover cells stressed by conjugative transfer, electroporation, or possibly even the presence of a plasmid per se and we strongly suspect that most potential transformants/transconjugants are lost when bacteria are plated on agar-solidified medium. Reliable electro-transformation, in combination with a segregationally unstable replicon, such as that of pCB102, may yet provide a way of obtaining detectable homologous recombination and thus facilitate functional analysis of the bacterial cellulosome in vivo. It has recently been shown that UV irradiation of plasmid DNA enhances homologous recombination with the Mycobacterium tuberculosis chromosome (Hinds et al., 1999). It will be of interest to determine whether a similar effect is observed with C. cellulolyticum.

\section{ACKNOWLEDGEMENTS}

We thank T. Davies for plasmid pM.BsuF1 and J. I. Rood for plasmid pJIR418. We are grateful to H.-P. Fierobe and A. Bélaich for reading the manuscript. This work was supported by the Commission of European Communities FAIR programme (contract CT 95-0191 [DG 12 SSMA]) and by grants from the Centre National de la Recherche Scientifique and the Université de Provence.

\section{REFERENCES}

Anderson, K. L., Megehee, J. A. \& Varel, V. H. (1998). Conjugal transfer of transposon Tn1545 into the cellulolytic bacterium Eubacterium cellulosolvens. Lett Appl Microbiol 26, 35-37.

Awad, M. M., Bryant, A. E., Stevens, D. L. \& Rood, J. I. (1995). Virulence studies on chromosomal $\alpha$-toxin and $\theta$-toxin mutants 
constructed by allelic exchange provide genetic evidence for the essential role of $\alpha$-toxin in Clostridium perfringens-mediated gas gangrene. Mol Microbiol 15, 191-202.

Azeddoug, H. \& Reysset, G. (1991). Recognition sequence of a new methyl-specific restriction system from Clostridium acetobutylicum strain ABKn8. FEMS Microbiol Lett 78, 153-156.

Azeddoug, H., Hubert, J. \& Reysset, G. (1989). Characterization of a methyl-specific restriction system in Clostridium acetobutylicum strain N1-4081. FEMS Microbiol Lett 65, 323-326.

Azeddoug, H., Hubert, J. \& Reysset, G. (1992). Stable inheritance of shuttle vectors based on plasmid pIM13 in a mutant strain of Clostridium acetobutylicum. J Gen Microbiol 138, 1371-1378.

Bayer, E. A., Shimon, L. J. W., Shoham, Y. \& Lamed, R. (1998). Cellulosomes - structure and ultrastructure. J Struct Biol 124, 221-234.

Bélaich, J.-P., Tardif, C., Bélaich, A. \& Gaudin, C. (1997). The cellulolytic system of Clostridium cellulolyticum. J Biotechnol 57, 3-14.

Biswas, I., Gruss, A., Ehrlich, S. D. \& Maguin, E. (1993). Highefficiency gene inactivation and replacement system for Grampositive bacteria. J Bacteriol 175, 3628-3635.

Boyer, H. W. \& Roulland-Dussoix, D. (1969). A complementation analysis of the restriction and modification of DNA in Escherichia coli. J Mol Biol 41, 459-472.

Brehm, J. K., Pennock, A., Bullman, H. M. S., Young, M., Oultram, J. D. \& Minton, N. P. (1992). Physical characterization of the replication origin of the cryptic plasmid pCB101 isolated from Clostridium butyricum NCIB7423. Plasmid 28, 1-13.

Bruand, C., Le Chatelier, E., Ehrlich, S. D. \& Jannière, L. (1993). A 4th class of theta-replicating plasmids: the pAM $\beta 1$ family from Gram-positive bacteria. Proc Natl Acad Sci USA 90, 11668-11672.

Caillaud, F., Carlier, C. \& Courvalin, P. (1987). Physical analysis of the conjugative shuttle transposon Tn1545. Plasmid 17, 58-60.

Clewell, D. B. \& Flannagan, S. E. (1993). The conjugative transposons of Gram-positive bacteria. In Bacterial Conjugation, pp. 369-393. Edited by D. B. Clewell. New York: Plenum Press.

Collins, M. E., Oultram, J. \& Young, M. (1985). Identification of restriction fragments from two cryptic Clostridium butyricum plasmids that promote the establishment of a replication-defective plasmid in Bacillus subtilis. J Gen Microbiol 131, 2097-2105.

Courvalin, P. \& Carlier, C. (1986). Transposable multiple antibiotic resistance in Streptococcus pneumoniae. Mol Gen Genet $\mathbf{2 0 5}$, 291-297.

Courvalin, P. \& Carlier, C. (1987). Tn1545: a conjugative shuttle transposon. Mol Gen Genet 206, 259-264.

Davis, T. O., Henderson, I., Brehm, J. K. \& Minton, N. P. (2000). Development of a transformation and gene reporter system for group II, non-proteolytic Clostridium botulinum type B strains. J Mol Microbiol Biotechnol 2, 59-69.

Doi, R. H., Park, J.-S., Liu, C.-C., Malburg, L. M., Tmaru, Y., Ichiishi, A. \& Ibrahim, A. (1998). Cellulosome and non-cellulosomal cellulases of Clostridium cellulovorans. Extremophiles 2, 53-60.

Ehrlich, S. D., Bruand, C., Sozhamannan, S., Dabert, P., Gros, M. F., Jannière, L. \& Gruss, A. (1991). Plasmid replication and structural stability in Bacillus subtilis. Res Microbiol 142, 869-873.

Evans, V. J., Liyanage, H., Ravagnani, A., Young, M. \& Kashket, E. R. (1998). Truncation of peptide deformylase reduces the growth rate and stabilizes solvent production in Clostridium beijerinckii NCIMB 8052. Appl Environ Microbiol 64, 1780-1785.
Felix, C. R. \& Ljungdahl, L. G. (1993). The cellulosome: the exocellular organelle of Clostridium. Annu Rev Microbiol 47, 791-819.

Franke, A. E. \& Clewell, D. B. (1981). Evidence for a chromosomeborne resistance transposon (Tn916) in Streptococcus faecalis that is capable of "conjugal" transfer in the absence of a conjugative plasmid. J Bacteriol 145, 494-502.

Gal, L., Pagès, S., Gaudin, C., Bélaich, A., Reverbel-Leroy, C., Tardif, C. \& Bélaich, J.-P. (1997). Characterization of the cellulolytic complex (cellulosome) produced by Clostridium cellulolyticum. Appl Environ Microbiol 63, 903-909.

Garcia-Martinez, D. V., Shinmyo, A., Madia, A. \& Demain, A. L. (1980). Studies on cellulase production by Clostridium thermocellum. Eur J Appl Microbiol Biotechnol 9, 189-197.

Garnier, T. \& Cole, S. T. (1988). Complete nucleotide sequence and genetic organization of the bacteriocinogenic plasmid, pIP404, from Clostridium perfringens. Plasmid 19, 134-150.

Gelhaye, E., Gehin, A. \& Petitdemange, H. (1993a). Colonization of crystalline cellulose by Clostridium cellulolyticum ATCC 35319. Appl Environ Microbiol 59, 3154-3156.

Gelhaye, E., Petitdemange, H. \& Gay, R. (1993b). Adhesion and growth rate of Clostridium cellulolyticum ATCC 35319 on crystalline cellulose. J Bacteriol 175, 3452-3458.

Giallo, J., Gaudin, C. \& Bélaich, J.-P. (1985). Metabolism and solubilization of cellulose by Clostridium cellulolyticum $\mathrm{H} 10$. Appl Environ Microbiol 49, 1216-1221.

Green, E. M., Boynton, Z. L., Harris, L. M., Rudolph, F. B., Papoutsakis, E. T. \& Bennett, G. N. (1996). Genetic manipulation of acid formation pathways by gene inactivation in Clostridium acetobutylicum ATCC 824. Microbiology 142, 2079-2086.

Gruss, A. \& Ehrlich, S. D. (1988). Insertion of foreign DNA into plasmids from Gram-positive bacteria induces formation of highmolecular-weight plasmid multimers. J Bacteriol 170, 1183-1190.

Gruss, A. \& Ehrlich, S. D. (1989). The family of highly interrelated single-stranded deoxyribonucleic-acid plasmids. Microbiol Rev 53, 231-241.

Guedon, E., Payot, S., Desvaux, M. \& Petitdemange, H. (1999a). Carbon and electron flow in Clostridium cellulolyticum grown in chemostat culture on synthetic medium. J Bacteriol 181, 3262-3269.

Guedon, E., Payot, S., Desvaux, M. \& Petitdemange, H. (1999b). Growth inhibition of Clostridium cellulolyticum by an inefficiently regulated carbon flow. Microbiology 145, 1831-1838. Hanahan, D. (1985). Techniques for transformation of E. coli. In DNA Cloning, a Practical Approach, vol. 1, pp. 109-135. Edited by D. M. Glover. Oxford: IRL Press.

Hedges, R. W. \& Jacob, A. E. (1974). Transposition of ampicillin resistance from RP4 to other replicons. Mol Gen Genet 132, $31-34$

Hinds, J., Mahenthiralingam, E., Kempsell, K. E., Duncan, K., Stokes, R. W., Parish, T. \& Stoker, N. G. (1999). Enhanced gene replacement in mycobacteria. Microbiology 145, 519-527.

Kok, J., van der Vossen, J. M. B. M. \& Venema, G. (1984). Construction of plasmid cloning vectors for lactic streptococci which also replicate in Bacillus subtilis and Escherichia coli. Appl Environ Microbiol 48, 726-731.

LeBlanc, D. J. \& Lee, L. N. (1984). Physical and genetic analyses of streptococcal plasmid $\mathrm{pAM} \beta 1$ and cloning of its replication region. J Bacteriol 157, 445-453.

Leenhouts, K. J., Olner, B., Bron, S., Kok, J., Venema, G. \& Sleegers, J. F. M. L. (1991). Nucleotide sequence and charac- 
terization of the broad-host-range lactococcal plasmid pWV01. Plasmid 26, 55-66.

Maguin, E., Duwat, P., Hege, T., Ehrlich, S. D. \& Gruss, A. (1992). New thermosensitive plasmid for Gram-positive bacteria. J Bacteriol 174, 5633-5638.

Mermelstein, L. \& Papoutsakis, E. T. (1993). In vivo methylation in Escherichia coli by the Bacillus subtilis phage $\phi 3 \mathrm{Ti}$ methyltransferase to protect plasmids from restriction upon transformation of Clostridium acetobuytlicum ATCC824. Appl Environ Microbiol 59, 1077-1081.

Minton, N. P. \& Morris, J. G. (1981). Isolation and partial characterization of three cryptic plasmids from strains of Clostridium butyricum. J Gen Microbiol 127, 325-331.

Minton, N. P., Brehm, J. K., Swinfield, T.-J., Whelan, S. M., Mauchline, M. L., Bodsworth, N. \& Oultram, J. D. (1993). Clostridial cloning vectors. In The Clostridia and Biotechnology, pp. 119-150. Edited by D. R. Woods. Boston: ButterworthHeinemann.

Monod, M., Dnoya, C. \& Dubnau, D. (1986). Sequence and properties of pIM13, a macrolide-lincosmide-streptogramin B resistance plasmid from Bacillus subtilis. J Bacteriol 167, 138-147.

Mullany, P., Wilks, M. \& Tabaqchali, S. (1991). Transfer of Tn916 and $\operatorname{Tn} 916 \Delta \mathrm{E}$ into Clostridium difficile: demonstration of a hotspot for these elements in the C. difficile genome. FEMS Microbiol Lett 79, 191-194.

Noirot, Ph., Petit, M.-A. \& Ehrlich, S. D. (1987). Plasmid replication stimulates DNA recombination in Bacillus subtilis. J Mol Biol 196, 39-47.

Oultram, J. D., Loughlin, M., Swinfield, T.-J., Brehm, J. K., Thompson, D. E. \& Minton, N. P. (1988). Introduction of plasmids into whole cells of Clostridium acetobutylicum by electroporation. FEMS Microbiol Lett 56, 83-88.

Pagès, S., Gal, L., Bélaich, A., Gaudin, C., Tardif, C. \& Bélaich, J.-P. (1997). Role of scaffolding protein CipC of Clostridium cellulolyticum in cellulose degradation. J Bacteriol 179, 2810-2816.

Pagès, S., Bélaich, A., Fiérobe, H.-P., Tardif, C., Gaudin, C. \& Bélaich, J.-P. (1999). Sequence analysis of scaffolding protein CipC and ORFXp, a new cohesin-containing protein in Clostridium cellulolyticum: comparison of various cohesin domains and subcellular localization of ORFXp. J Bacteriol 181, 1801-1810.

Payot, S., Guedon, E., Cailliez, C., Gelhaye, E. \& Petitdemange, H. (1998). Metabolism of cellobiose by Clostridium cellulolyticum growing in continuous culture: evidence for decreased $\mathrm{NADH}$ reoxidation as a factor limiting growth. Microbiology 144, 375-384.

Petitdemange, E., Caillet, F., Giallo, J. \& Gaudin, C. (1984). Clostridium cellulolyticum sp. nov., a cellulolytic, mesophilic species from decayed grass. Int J Syst Bacteriol 34, 155-159.

Reverbel-Leroy, C., Pagès, S., Bélaich, A., Bélaich, J.-P. \& Tardif, C. (1997). The processive endocellulase CelF, a major component of the Clostridium cellulolyticum cellulosome: purification and characterization of the recombinant form. J Bacteriol 179, 46-52.

Sambrook, J., Fritsch, E. F. \& Maniatis, T. (1989). Molecular Cloning: a Laboratory Manual, 2nd edn. Cold Spring Harbor, NY: Cold Spring Harbor Laboratory.

Scott, J. R. \& Churchward, G. G. (1995). Conjugative transposition. Annu Rev Microbiol 49, 367-397.

Shoham, Y., Lamed, R. \& Bayer, E. A. (1999). The cellulosome concept as an efficient microbial strategy for the degradation of insoluble polysaccharides. Trends Microbiol 7, 275-281.

Sloan, J., Warner, T. A., Scott, P. T., Bannan, T. L., Berryman, D. I. \& Rood, J. I. (1992). Construction of a sequenced Clostridium perfringens-Escherichia coli shuttle plasmid. Plasmid 27, 207-219.

Southern, E. M. (1975). Detection of specific sequences among DNA fragments separated by gel electrophoresis. J Mol Biol 98, 503-517.

Thomas, C. M. \& Smith, C. A. (1987). Incompatiblity group P plasmids: genetics, evolution, and use in genetic manipulation. Annu Rev Microbiol 41, 77-101.

Trieu-Cuot, P., Carlier, C., Martin, P. \& Courvalin, P. (1987). Plasmid transfer by conjugation from Escherichia coli to Grampositive bacteria. FEMS Microbiol Lett 48, 289-294.

Walter, J., Noyerweidner, M. \& Trautner, T. A. (1990). The aminoacid-sequence of the CCGG recognizing DNA methyltransferase M.BsuFI - implications for the analysis of sequence recognition by cytosine DNA methyltransferases. EMBO J 9, 1007-1013.

Wilkinson, S. \& Young, M. (1994). Targeted integration of genes into the Clostridium acetobutylicum chromosome. Microbiology 140, 89-95.

Williams, D. R., Young, D. I., Oultram, J. D., Minton, N. P. \& Young, M. (1990a). Development and optimization of conjugative plasmid transfer from Escherichia coli to Clostridium acetobutylicum NCIB 8052. In Clinical and Molecular Aspects of Anaerobes, pp. 239-246. Edited by S. P. Boriello. Petersfield, UK: Wrightson Biomedical.

Williams, D. R., Young, D. I. \& Young, M. (1990b). Conjugative plasmid transfer from Escherichia coli to Clostridium acetobutylicum. J Gen Microbiol 136, 819-826.

Woolley, R. C., Pennock, A., Ashton, R. J., Davies, A. \& Young, M. (1989). Transfer of Tn1545 and Tn916 to Clostridium acetobutylicum. Plasmid 22, 169-174.

Young, M. (1993a). Development and exploitation of conjugative gene transfer in clostridia. In The Clostridia and Biotechnology, pp. 99-117. Edited by D. R. Woods. Boston: ButterworthHeinemann.

Young, M. (1993b). Conjugative gene transfer in clostridia. In Genetics and Molecular Biology of Anaerobic Bacteria, pp. 98-110. Edited by M. Sebald. New York: Springer.

Young, M. \& Cole, S. T. (1993). Clostridium. In Bacillus subtilis and Other Gram-positive Bacteria: Biochemistry, Physiology, and Molecular Genetics, pp. 35-52. Edited by A. L. Sonenshein, J. A. Hoch \& R. Losick. Washington, DC: American Society for Microbiology.

Young, M. \& Ehrlich, S. D. (1989). Stability of reiterated sequences in the Bacillus subtilis chromosome. J Bacteriol 171, 2653-2656.

Young, D. I., Williams, D. R. \& Young, M. (1993). Evidence for transfer of a single DNA strand during IncP-mediated conjugative mobilization of plasmids from E. coli to Gram-positive bacteria. In DNA Transfer and Gene Expression in Micro-organisms, pp. 131-135. Edited by E. Balla, G. Berencsi \& A. Szentirmai. Andover, UK: Intercept.

Young, D. I., Evans, V. J., Jefferies, J. R., Jennert, K. C. B., Phillips, Z. E. V., Ravagnani, A. \& Young, M. (1999). Genetic methods in clostridia. Methods Microbiol 29, 191-207.

Received 22 June 2000; revised 3 August 2000; accepted 30 August 2000 